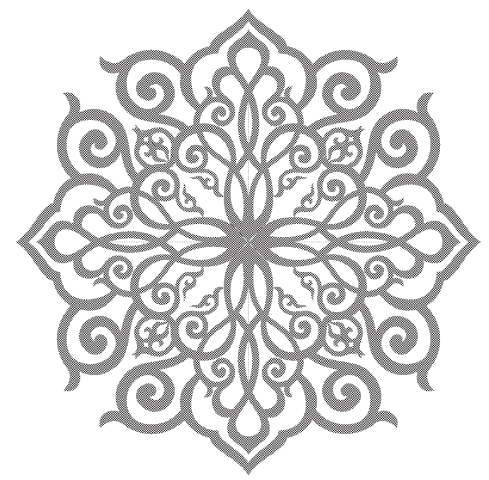





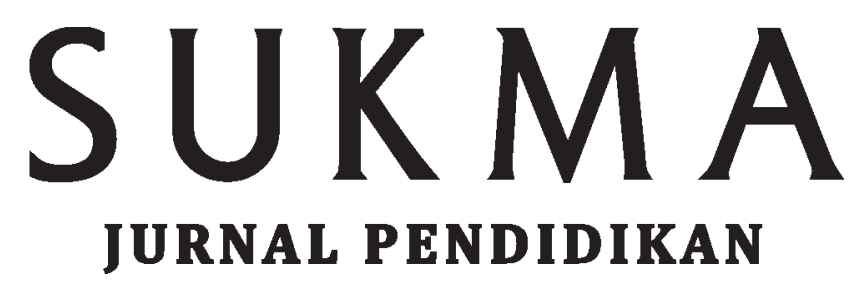




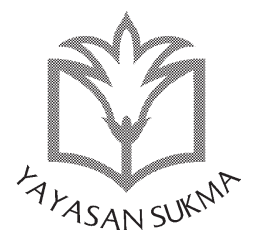

\section{SUKMA: JURNAL PENDIDIKAN}

ISSN: 2548-5105 (p), 2597-9590 (e) Volume 3 Issue 2, Jul-Dec 2019

\section{REVIEWER AHLI}

H.A.R. Tilaar - Indonesia Academy of Sciences

Komaruddin Hidayat - Universitas Islam Negeri Syarif Hidayatullah Jakarta, Indonesia

Eero Ropo - Tampere University, Finland

Pekka Raiha - Tampere University, Finland

Pasi Kaskinen - Finland University, Finland

Ahmad Baedowi - Yayasan Sukma Jakarta, Indonesia

Khoiruddin Bashori - Universitas Ahmad Dahlan Yogyakarta, Indonesia

Syamsir Alam - Badan Akreditasi Sekolah dan Madrasah Indonesia

Fuad Fachruddin - Sekolah Sukma Bangsa Aceh, Indonesia

\section{EDITOR-IN-CHIEF}

Ratno Lukito - Universitas Islam Negeri Sunan Kalijaga Yogyakarta, Indonesia

\section{EDITORS}

Evy I. Siregar - Sekolah Sukma Bangsa Aceh, Indonesia

Khairil Azhar - Sekolah Sukma Bangsa Lhokseumawe, Aceh, Indonesia

Satia Prihatni Zen - Sekolah Sukma Bangsa Bireuen, Aceh, Indonesia

Saptoni - Universitas Islam Negeri Sunan Kalijaga Yogyakarta, Indonesia 


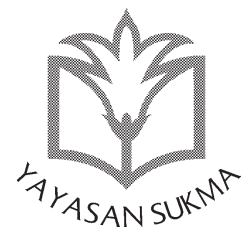

\section{SUKMA: JURNAL PENDIDIKAN}

ISSN: 2548-5105 (p), 2597-9590 (e) Volume 3 Issue 2, Jul-Dec 2019

SUKMA: Jurnal Pendidikan adalah jurnal ilmiah yang terbit di Indonesia dalam bidang pendidikan. Terbit dua kali setahun (biannual), jurnal ini mengimplementasikan sepenuhnya proses penelaahan sejawat (peer-review) dari para ahli pendidikan di tanah air maupun luar negeri dalam penerbitan artikelnya. Sebagai open access journal, artikel SUKMA: Jurnal Pendidikan dapat diakses secara bebas di https://jurnalsukma.org.

SUKMA: Jurnal Pendidikan diterbitkan pertama kali pada bulan Januari 2017; Nomor ISSN: 2548-5105 (SK ISSN Nomor 0005.25485105/JI.3.1/SK.ISSN/2016.12, tanggal 8 Desember 2016); dan e-ISSN: 2597-9590 (SK ISSN Nomor 0005.25979590/JI.3.1/SK.ISSN/2017.09, tanggal 25 September 2017).

SUKMA: Jurnal Pendidikan terakreditasi ARJUNA/SINTA dengan peringkat 4.

\section{PENERBIT}

\section{Yayasan Sukma}

Jln. Pilar Mas Raya Kavling A-D, Kedoya Kebun Jeruk Jakarta 11520 - Indonesia Telp. +62 2158300077 Fax. +62 215818175 www.yayasan-sukma.org 



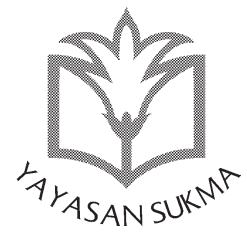

\section{SUKMA: JURNAL PENDIDIKAN}

ISSN: 2548-5105 (p), 2597-9590 (e) Volume 3 Issue 2, Jul-Dec 2019

\section{DAFTAR ISI}

Editorial

ix-xiii

Kebijakan Kurikulum dan Dinamika Penguatan Pendidikan Karakter di Indonesia

Mohammad Ariandy

The Relation of Care-Giver Language and Children's Knowledge Construction: It's Impact on Literacy Achievement

Evy I. Siregar

Motivational Factors to Learn English among University Students in An Urban Area

Reza Anggriyashati Adara

Penggunaan Kata dan Istilah Bahasa Inggris pada Promosi Penjualan Online di Instagram

Nurul Fadzilatul Husna; Siva Nur Azizah; Mokh Yahya 203-216 
SUKMA: Jurnal Pendidikan, Volume 3 Issue 2, Jul-Dec 2019

Identifikasi Sikap Rasa Ingin Tahu Siswa terhadap

Pembelajaran Fisika di MAN 1 Batanghari

Irma Fadilah; Kartini

Book Review: Pedagogi Cinta

Fuad Fachruddin

233-259 